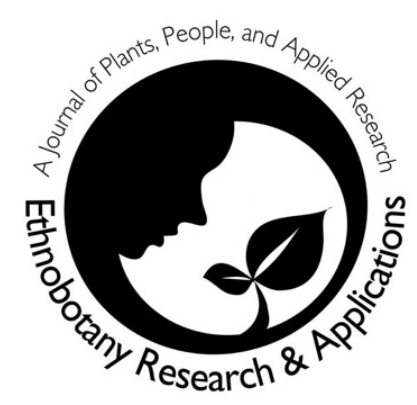

\title{
Medicinal plants used for diabetic problems in the Rif, Morocco
}

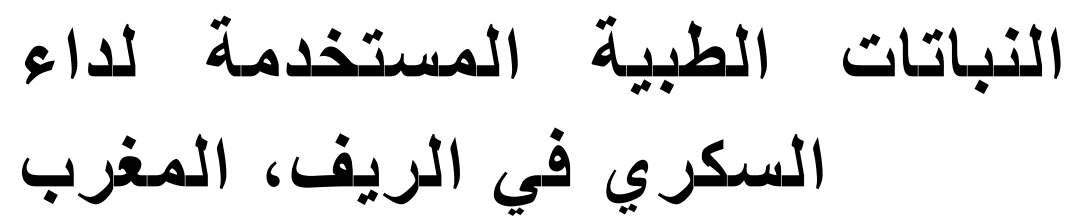

Noureddine Chaachouay, Ouafae Benkhnigue, Hamid El Ibaoui, Rachida El Ayadi, Lahcen Zidane

\section{Research}

\begin{abstract}
Background: since early times, the people of Morocco use medicinal plants as traditional medicine to treat diabetes. However, little studies have been made in the past to properly document and promote the traditional knowledge. This study was carried out in the Rif (North of Morocco), it aimed to identify medicinal plant used by the local people to treat diabetic problems, together with the associated ethnomedicinal knowledge.
\end{abstract}

Materials and Methods: The ethnomedical information collected was from 582 traditional healers using semi-structured interviews, free listing and focus group. Family use value (FUV), use value (UV), plant part value (PPV) and informant agreement ratio (IAR) were employed in data analysis. Medicinal plants were collected, identified and kept at the natural resources and biodiversity laboratory, Ibn Tofail University, Kenitra.

Results: During the present study 30 medicinal plant species belonging to 14 families has been documented. The most frequent ailments reported were type 1 diabetes. The majority of the remedies were prepared from infusion. Leaves were the most frequently used plant part and Rosmarinus officinalis L. was the species most commonly prescribed by local herbalists.

Conclusions: The results of this study showed that people Arabs and Imazighen living in the Rif of Morocco are still dependent on medicinal plants. The documented medicinal plants can serve as a basis for further studies on the regions, medicinal plants knowledge and for future phytochemical and pharmacological studies.

Keywords: Rif; Ethnomedicinal; Medicinal plants; Diabetic problems.

\section{Correspondence}

Noureddine Chaachouay*, Ouafae Benkhnigue, Hamid EI Ibaoui, Rachida EI Ayadi, Lahcen Zidane

Natural Resources and Biodiversity Laboratory, Department of Biology, Faculty of Sciences, Ibn Tofail University, BP 133 14000, Kenitra, Morocco

*Corresponding author: our.chay@gmail.com BP 106 Kenitra Road, Said Hajji, 11150 Sale, Morocco; Tel: +212677488621

\section{Ethnobotany Research \& Applications} 18:21 (2019)

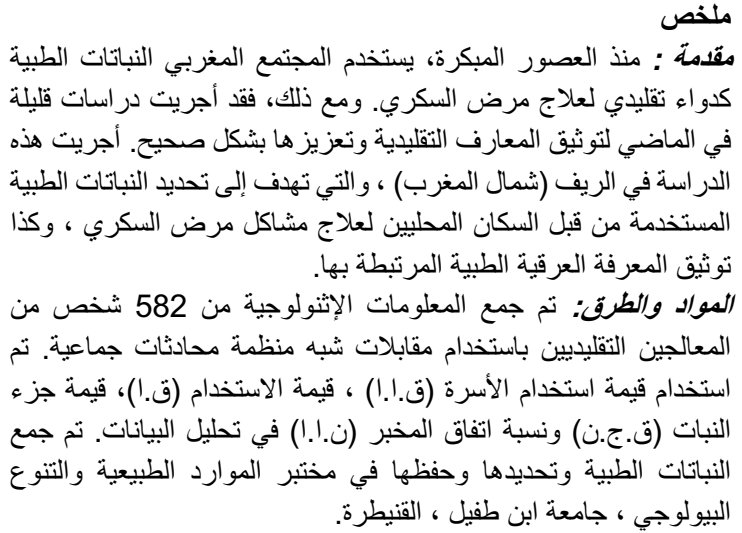




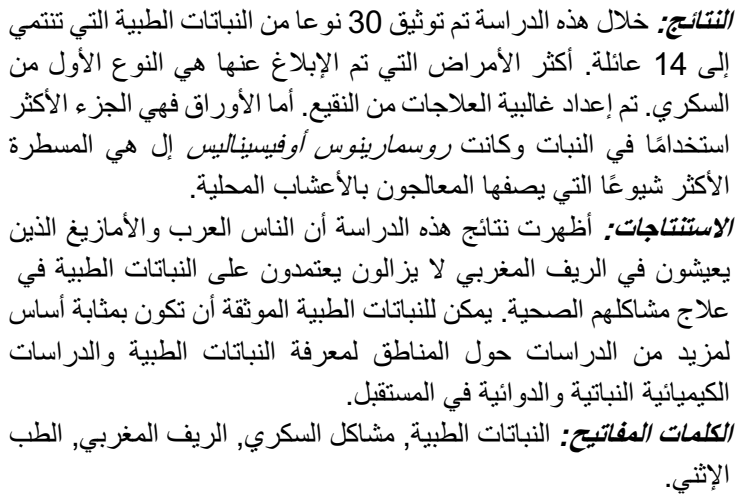

Introduction

Diabetes mellitus is a metabolic disorder characterized by the presence of hyperglycemia due to defective insulin secretion, defective insulin action or both. The chronic hyperglycemia of diabetes is associated with relatively specific long-term microvascular complications affecting the eyes, kidneys and nerves, as well as an increased risk for cardiovascular disease (Goldenberg and Punthakee 2013).

Morocco is one of the 19 countries and territories of the international diabetes federation (IDF) Middle East and North Africa (MENA) region. 425 million people have diabetes in the world and more than 39 million people in the MENA Region; by 2045 this will rise to 67 million. There were 1.641 .900 cases of diabetes in Morocco in 2017 (International Diabetes Federation 2019).

Nowadays, different treatments, such as insulin therapy, pharmacotherapy, and diet therapy, are available to control diabetes. The World Health Organization expert committee on diabetes has listed as one of its recommendations that traditional methods of treatment of diabetes should be further investigated (Committee 2009).

Currently, the main and effective treatment for diabetes is the use of insulin and hypoglycemic drugs, but these compounds also have many adverse side effects (Graham et al. 2007). Medicinal plants have a long history of usage and today, they are being extensively used for various diseases (Karami et al. 2017; Rabiei et al. 2016). There are several reasons for increasing the use of medicinal plants. Many plants from different parts of the world have been investigated for antidiabetic effects

The purpose of the present investigations was to evaluate MPs that grow in the study area with the aim to contribute to indigenous knowledge of MPs and to analyze the results concerning the existing relationships between medicinal species and diabetic problems. Indeed, it is very important to transform this traditional knowledge into scientific knowledge in order to revalue it, to preserve it and use it rationally.

\section{Materials and methods}

Description of the study area

The present study was conducted in the Rif (northern Morocco) it is located on the Mediterranean coast, about $431 \mathrm{~km}$ at the north of Rabat, the administrative capital. The Rif is part of the region of Tangier-Tetouan-Al Hoceima which is one of the twelve regions of Morocco established by the territorial division of 2015 (Bulletin officiel 2015). This study area (between $34^{\circ}$ to $36^{\circ} \mathrm{N}$ latitude and $4^{\circ}$ to $6^{\circ} \mathrm{E}$ longitude) is limited to the north by the Strait of Gibraltar and the Mediterranean Sea, to the west by the Atlantic Ocean, to the south-west by the RabatSale-Kenitra region, to the south-east by the FezMeknes region and to the east by the Eastern region. The region has two prefectures (Tangier-Asilah and M'Diq-Fnideq) and six provinces (Al Hoceima, Chefchaouen, Fahs-Anjra, Larache, Ouezzane and Tetouan) and the region's capital, Tangier-Asilah as shown in Fig. 1.

According to the 2014 national census report (HCP 2018 ), the total area of study area is about 11,570 $\mathrm{km}^{2}$ with an average population density of $222.2 / \mathrm{km}^{2}$, and the human population is 3 549512. The study area has Mediterranean climate with maximum temperature beyond $45^{\circ} \mathrm{C}$ during summer (JulyAugust) and below $0^{\circ} \mathrm{C}$ during winter (DecemberJanuary) and annual rainfall is about $1000 \mathrm{~mm}$. In the area, economy of the local people is very much dependent on subsistence agriculture, livestock and to a lesser extent, from forest resources for their livelihood. Inhabitants of the region use variety of MPs for the treatment ailments due to expensive drugs Fig 2.

\section{Methodology}

Data collection tools and procedures

In order to gather information on MPs used for curing diabetic problems, an ethnobotanical survey was conducted from June $30 \mathrm{t}^{\mathrm{t}}$, 2016 to June $1^{\text {st }}, 2018$. Semi-structured questionnaires were administered, and free listings were conducted, through face to face interviews and focus group. The inclusion criteria were people who are knowledgeable about plants used for diabetic problems, while the exclusion criteria were informants who are not living in the study area. Totally, 582 informants within aged 17 to 92 were randomly selected for interviews (pharmacists, herbalists, practitioners and therapists) in the study area (hospitals, pharmacies, houses, mosques, and weekly markets). Who have been informed about the objective of this study, after obtaining their trust and were regularly interviewed in Amazigh or Arabic dialects depending on the variety 
of language spoken by each case, in order to collect and document indigenous knowledge of plants usage against diabetic problems. The questionnaire used consists of two parts: the first part deals with the demographic characteristic of the informants and the second one focuses on the plants used in the treatment of the problems (Appendix A). The sample is made up of 311 females and 271 males from different socio-economic strata, chosen at random from the Rif's population. In this study, the sample is developed using a stratified random sampling method (Godron 1971) to conduct various surveys from a site to another in the study area. According to this sampling method, we have divided our study area into sites $(\mathrm{Sn})$, so we have 28 sites that correspond to the number of divisions in the study area (Fig. 3).

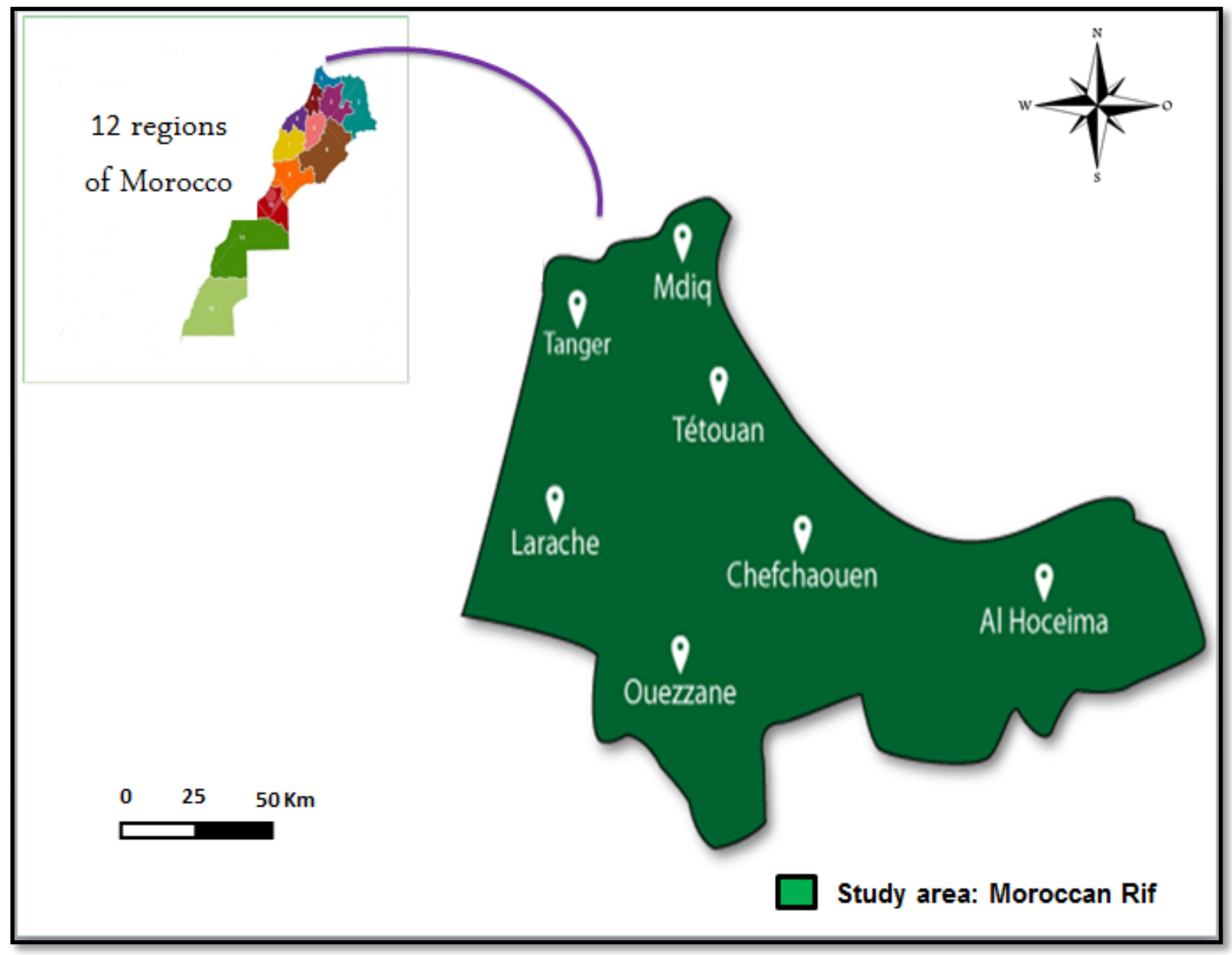

Fig. 1. Map of the study area

Plant species identification and preservation

Standard method was followed with record to collection of plant materials, drying, mounting, preparation and preservation of plant specimens (Jain 1964). MPs species in bi-plicate were collected prepared and identified. Plants with their correct nomenclature were arranged alphabetically by family name and vernacular name ethnomedicinal uses. The identification and nomenclature of the listed plants were based on the medicinal plants of the Morocco (Sijelmassi 1993), Practical flora of Morocco (Fennane et al. 1999) and Catalogs of vascular plants of northern Morocco, including identification keys (Valdés 2002), volumes I and II. They were later verified at resources and biodiversity laboratory, department of biology faculty of sciences, Ibn Tofail University Kenitra, Morocco. All the preserved specimens were deposited at the Herbarium of Ibn Tofail University.

\section{Data Analysis}

A descriptive and quantitative statistical method was used to analyze the socio-demographic data of the informants (ANOVA One-way and Independent Samples T-Test, P-values of 0.05 or less were considered significant). The results of the 
ethnobotanical survey were analyzed using the Family Use Value (FUV), Use Value (UV), Use Report (UR), Plant Part Value (PPV), Fidelity Level $(F L)$ and Informant Agreement Ratio (IAR). All

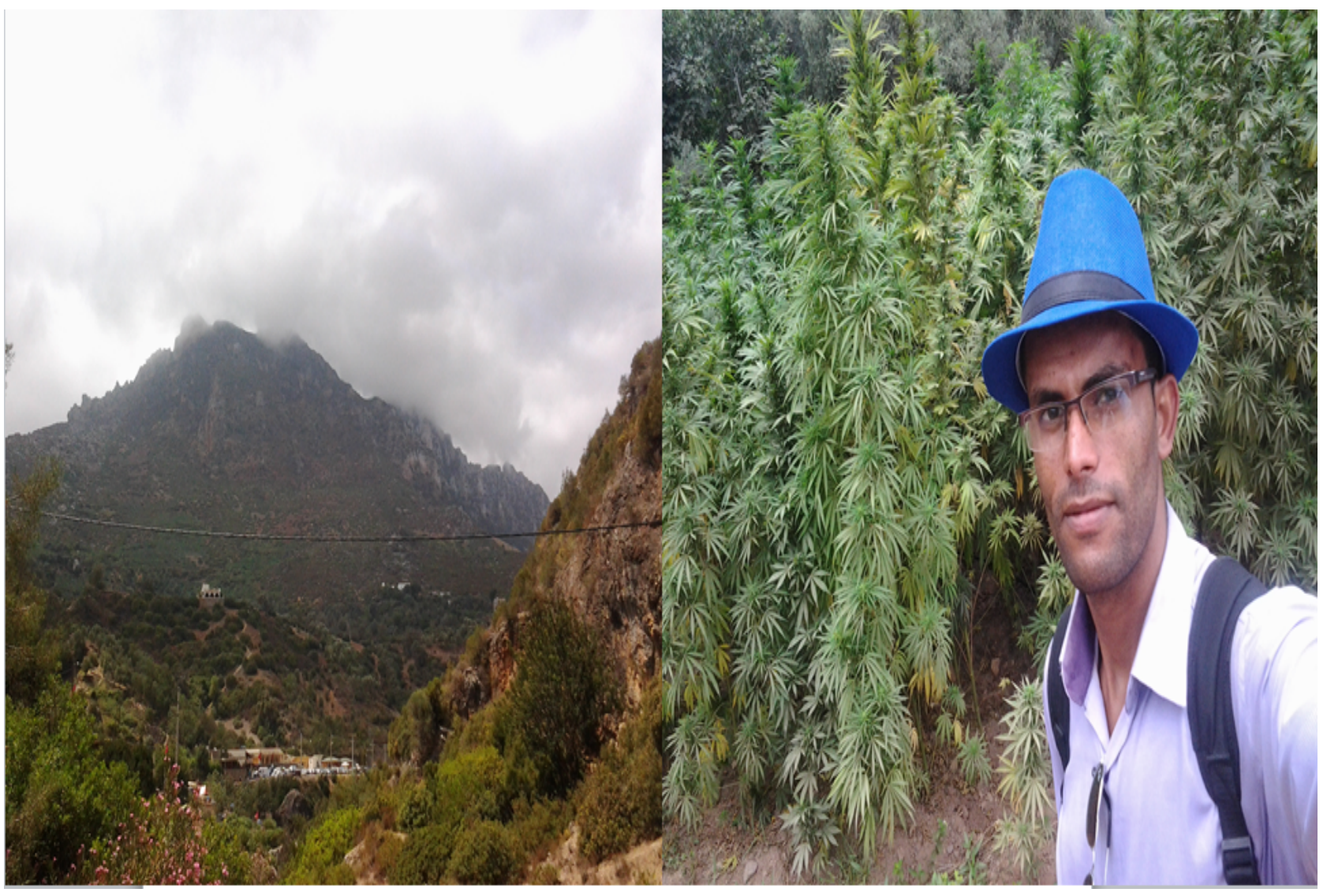

statistical analyses were carried out with Statistical Package for Social Science (SPSS) version 21 and Microsoft Excel 2010.
Fig. 2. Landscape of the rural community Akchour

\section{Family Use Value (FUV)}

The FUV identify the significance of plants families. It is as an index of cultural importance which can be applied in ethnobotany to calculate a value of biological plant taxon. To calculate FUV, we use the following formula: FUV $=\frac{U V s}{N_{S}}$. Where UVs $=U V$ is the number of informants mentioning the family and Ns is the total number of species within each family (Sreekeesoon and Mahomoodally 2014).

\section{Use value (UV)}

The use value of species (UV), a quantitative method that demonstrates the relative importance of species known locally (Vitalini et al. 2013), was also calculated according to the following formula: UV = $\frac{\sum U_{i}}{\mathrm{~N}}$. Where $\mathrm{U}_{i}$ is the number of use reports mentioned by each informant (i) and $\mathrm{N}$ is the total number informants interviewed for a given plant species. 


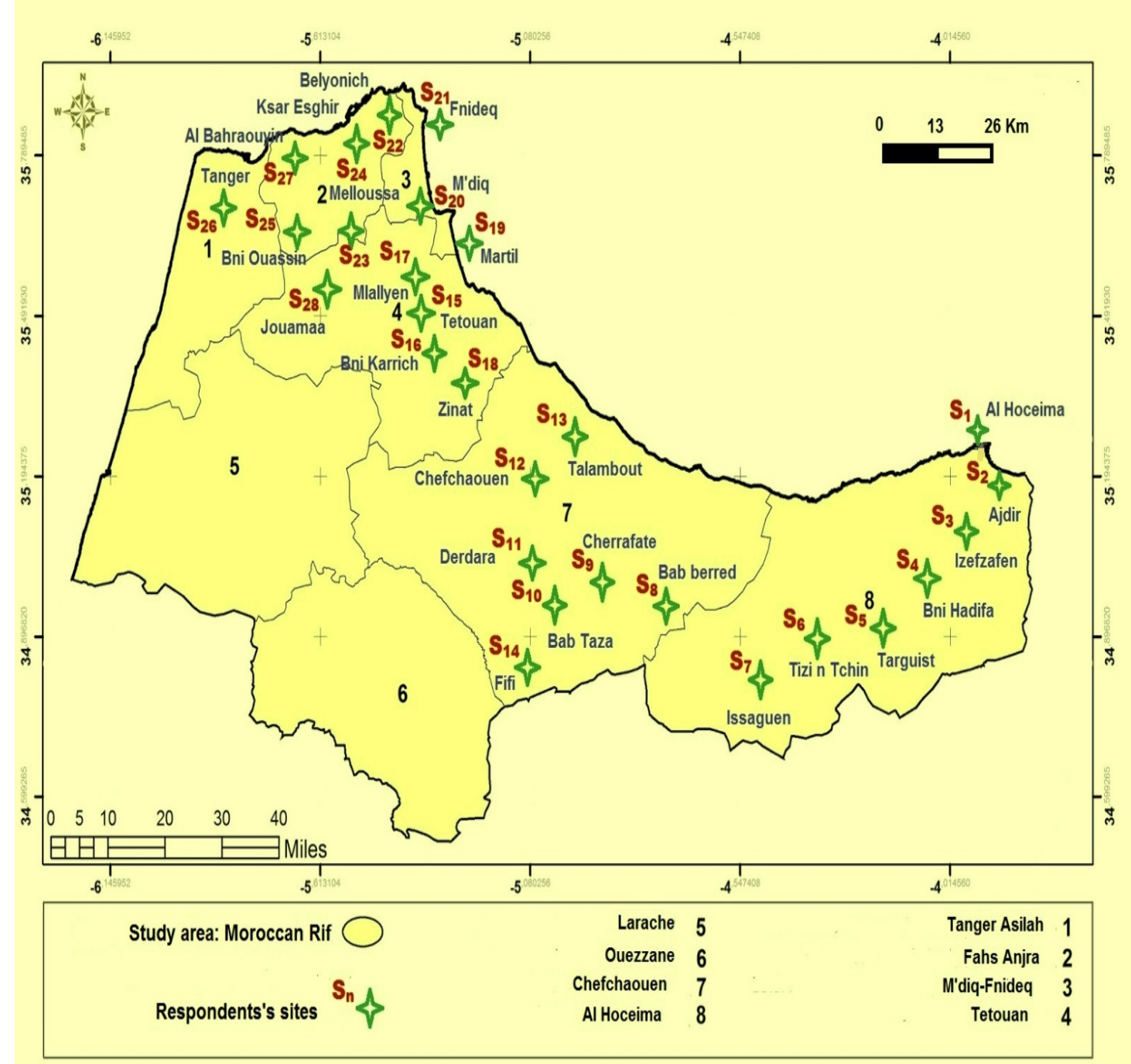

Fig. 3. Distribution of survey points at the study area level.

\section{Results and discussion}

Socio-demographic features of the informants In total, 582 respondents belonging to 2 ethnic groups (311 men and 271 women with a sex ratio female/male of 1.15) were randomly selected at the Rif's area. Comparative data of the sampling composition can be observed in the Table 1.

In this study, both sexes are affected by traditional phytotherapy. The ethnic groups with the highest numbers are the Arabs 313 (53.8). The gender distribution among Imazighen showed that $51.6 \%$ of the respondents were males and $55.6 \%$ were females, among the Arabs, $48.4 \%$ were males and $44.4 \%$ were females. In both groups, women have a greater knowledge on the plant species. The result of independent sample $t$ test indicated that there is a significant knowledge difference between male and female informants for Arabs $\left(X^{2}=0.34, d f=1, P=\right.$ $0.514)$ and not significantly for Imazighen $\left(X^{2}=\right.$
9.058, $\mathrm{df}=1, \mathrm{P}=0.004)$. This predominance of females can be explained by the vigilance of women for the balance of the disease, and their attachment to all that is traditional; indeed, it is women who give sustenance and healthcare to their families in case of an illness. These results confirm the results of other ethnobotanical work carried out at national scale (Jouad et al. 2001; Salhi et al. 2010; Tahraoui et al. 2007; Ziyyat et al. 1997).

In our study, the informants involved in the present study were 17-92 years old. From the total informants, $(50.7 \%)$ were in the age range of $40-60$ (57.6\% Arabs and $42.4 \%$ Imazighen), while $23 \%$ of the informants were more than 60 years old $(51.5 \mathrm{per}$ cent of whom are Arabs), $22.8 \%$ were in the age range of 20-40 years old (49.6 per cent of whom are Imazighen) and informants with an age less than 20 come in last position with a rate of $3.5 \%$ (including $65 \%$ Imazighen and $35 \%$ Arabs) Table 1 . In both 
ethnolinguistic group, significant differences $(P=$ 0.000 ) were obtained by ANOVA One-way between age groups and indigenous knowledge. The highest age respondents provide more reliable information because they hold much of the ancestral knowledge that is part of the oral tradition. So there is a loss of information on MPs, which can be explained by the mistrust of certain young people, who tend disinterest on this herbal medicine due to the influence of modernization and exotic culture influence. At present, the traditional medical knowledge transmitted from generation to generation is in danger, because transmission between old people and younger generation is not always assured (Anyinam 1995). These values confirm the results obtained in other regions of Morocco (Aribi 2013; Benlamdini et al. 2014; El Hafian et al. 2014). Altogether, in the two human groups analyzed, fieldwork overall generated more ethnobotanical information, of the total informants, most informants (313) were Arabs (including 233 married, 46 divorced, 63 widowers and 5 singles), 269 of them were Imazighen (including 192 married, 51 divorced, 17 widowers and 9 singles), because the married informants can avoid or minimize the material charges required by the doctor and the pharmacist. The difference between family status and indigenous knowledge for the treatment of diabetic diseases by Imazighen and Arabs was statistically significant $(P$ $=0.000)$. Those findings coincide with those of similar study conducted by (El Hilah et al. 2015) in the central plateau of Morocco.

Regarding the level of education, more than half of the informants (70.8\%) were illiterate including 200 Imazighen and 212 Arabs, and $(21.3 \%)$ of the informants had been primary school $(57.3 \%$ per cent of whom are Arabs), (7.2\%) of the informants had been secondary school (71.4 per cent of whom are Arabs). Nevertheless, informants with a university level education use little medicinal plants $(0.7 \%)$.
Thus, the difference between educational level and indigenous knowledge for both groups was significant $(P=0.000)$. We can therefore see that the use of MPs decreases as the level of study increases. This result is similar to the findings reported by (Bouzid et al. 2017; El Hafian et al. 2014; El Hilah et al. 2015; Lahsissene et al. 2009).

In our study, $46.3 \%$ of the interviewees had a low socio-economic level (55.5 per cent of whom are Arabs), (36.1\%) were unemployed including 48.6\% Imazighen and $51.4 \%$ Arabs, (16\%) with average level (53.8 per cent of whom are Arabs), and only $1.6 \%$ with higher level (55.6 per cent of whom are Arabs). In both ethnolinguistic groups, the difference between income/month and indigenous knowledge was significant $(P=0.000)$. The high cost of modern medical treatments and their side effects are among the main reasons why respondents used herbal medicine. We can therefore see that the use of plants increases with the increase in monthly income of these informants. These results are similar to those obtained in Moyen Moulouya of Morocco by (Douiri et al. 2007).

\section{Medicinal plant richness}

In total, we registered 30 plant species belonging to 14 botanical families were used to treat diabetic problems by two cultural groups from the study region. However, the number of medicinal plants used as traditional medicines varies between two ethnolinguistic groups Imazighen and Arabs. The Imazighen use 23 species in their home therapies, while Arabs reported 21 plants as medicinally useful. These plants are presented in alphabetical order. For each plant listed, we give the scientific name, the family, the local name, the part used, the method of preparation adopted by the local population, as well as the data of UR, UV and FUV are shown in Table 2.

Table 1. Comparative table with socioeconomic characteristics of the study area

\begin{tabular}{|c|c|c|c|c|c|c|c|}
\hline \multirow{2}{*}{ Variables } & \multicolumn{2}{|c|}{ Imazighen groups } & \multicolumn{2}{|c|}{ Arab groups } & \multirow[t]{2}{*}{ Total } & \multirow{2}{*}{$\begin{array}{l}\text { Percentages } \\
(\%)\end{array}$} & \multirow[t]{2}{*}{ P-values } \\
\hline & Number & $\%$ & Number & $\%$ & & & \\
\hline Gender & & & & & & & \multirow{3}{*}{$\begin{array}{l}0.514 \\
.0004\end{array}$} \\
\hline Female & 173 & 55.6 & 138 & 44.4 & 311 & 53.4 & \\
\hline Male & 140 & 51.6 & 131 & 48.4 & 271 & 46.6 & \\
\hline \multicolumn{7}{|l|}{ Age groups } & \multirow[t]{5}{*}{0.000} \\
\hline$<20$ years & 13 & 65 & 7 & 35 & 20 & 3.5 & \\
\hline $20-40$ & 66 & 49.6 & 67 & 51.4 & 133 & 22.8 & \\
\hline $40-60$ & 125 & 42.4 & 170 & 57.6 & 295 & 50.7 & \\
\hline$>60$ years & 65 & 48.5 & 69 & 51.5 & 134 & 23 & \\
\hline
\end{tabular}




\begin{tabular}{|l|l|l|l|l|l|l|l|}
\hline $\begin{array}{l}\text { Family } \\
\text { situation }\end{array}$ & & & & & & 0.000 \\
\hline Married & 192 & 45 & 233 & 55 & 425 & 73.6 & \\
\hline Divorced & 51 & 52.6 & 46 & 47.4 & 97 & 16.6 & \\
\hline Widower & 17 & 37 & 29 & 63 & 46 & 8 & \\
\hline Single & 9 & 64.3 & 5 & 35.7 & 14 & 2.3 & \multirow{2}{*}{0.000} \\
\hline $\begin{array}{l}\text { Educational } \\
\text { level }\end{array}$ & & & & & & & \\
\hline Illiterate & 200 & 48.54 & 212 & 51.46 & 412 & 70.8 & \\
\hline Primary & 53 & 42.7 & 71 & 57.3 & 124 & 21.3 & \\
\hline Secondary & 12 & 28.6 & 30 & 71.4 & 42 & 7.2 & \\
\hline University & 3 & 75 & 1 & 25 & 4 & 0.7 & \\
\hline Income/month & & & & & & & \\
\hline Unemployed & 102 & 48.6 & 107 & 51.4 & 210 & 36.1 & \\
\hline 250 - 1500 MAD & 120 & 45.5 & 150 & 55.5 & 270 & 46.3 & \\
\hline $\begin{array}{l}1500-5000 \\
\text { MAD }\end{array}$ & 43 & 46.2 & 50 & 53.8 & 93 & 16 & \\
\hline$>5000$ MAD & 4 & 44.4 & 5 & 55.6 & 9 & 1.6 & \\
\hline
\end{tabular}

Similarity and diversity of medicinal plants

In order to estimate species diversity and similarity, we considered the number of medicinal uses assigned to each medicinal plant. By analysing species similarity between the two ethnosociolinguistic groups, we observed that the coefficient of similarity of the plants species documented in the study area was shared between the two groups (Imazighen and Arabs) is $63.6 \%$. The longest lists of plant species used were found on Imazighen (23 plant species). The shortest lists were found on Arabs (21 plant species), as mentioned in Fig. 4. Using chi-square analysis, the number of mentions for medicinal plants used similar significantly between our interviewees Imazighen and Arabs $\left(x^{2}=203.48 d f=1, p\right.$ value $\left.=0.763\right)$. We conclude, therefore, that species diversity is the highest for the Imazighen group.

In both ethnosociolinguistic groups, the most representative families, in terms of number of species, were Asteraceae (6 species each) followed by Fabaceae and Moraceae (4 species each) and Lamiaceae (03 species), while other families were represented by two or single species (Fig. 5). Based on the FUV index, the 5 most cited families are Lamiaceae (FUV = 0.177), Cupressaceae (FUV = $0.136)$, Rosaceae (FUV $=0.130)$, Linaceae (FUV = 0.112 ) and Moraceae (FUV $=0.083$ ). This high proportion could be explained by the high representation of these families in the Rif's flora because of the ecological factors that favour the development and adaptation of the majority of their species. This partially coincides with the findings in other territories with similar characteristics (Bonet
2001; Eddouks et al. 2002; Ghourri et al. 2012; Jouad et al. 2001; Tahraoui et al. 2007).

\section{MAPs and their UV values}

The importance of MPs was assayed by use values (UV) that were ranged between 0.002 for the less used species and 0.170 for the most used species for each cultural group (Fig. 6). 23 species achieved use value (UV) for Imazighen people (with values between 0.002 and 0.170 ) the most important being: Rosmarinus officinalis L. (UV $=0.170)$, Salvia officinalis L. (UV = 0.101), Calendula arvensis M.Bieb. (UV = 0.096), Ficus abelii Miq. (UV = 0.086), Juniperus phoenicea L. (UV $=0.081)$ and Malus domestica Borkh. (UV = 0.074). 21 species resulted to be characteristic for Arabs with the highest UV values being: Rosmarinus officinalis $\mathrm{L}$. (UV $=0.155)$, Salvia officinalis L. (UV $=0.103)$, Ficus abelii Miq. $(\mathrm{UV}=0.091)$, Calendula arvensis M.Bieb. (UV = 0.069 ), Morus alba L. (UV $=0.065)$. It was noticed that MPs exhibiting higher UV (Rosmarinus officinalis L., Salvia officinalis L., Calendula arvensis M.Bieb. and Ficus abelii Miq. were found frequently in both ethnosociolinguistic groups Imazighen and Arabs and practiced in herbal therapies with higher uses than other plants. Those medicinal plant species with low UV are also very important and should not be ignored as failing to declare them to upcoming generations could raise the threat of slowly vanishing of the knowledge. Medicinal plant species having high UV must be further assessed for phytochemical and pharmaceutical analysis to identify their active constituents for any drug extraction (Vitalini et al. 2013). 


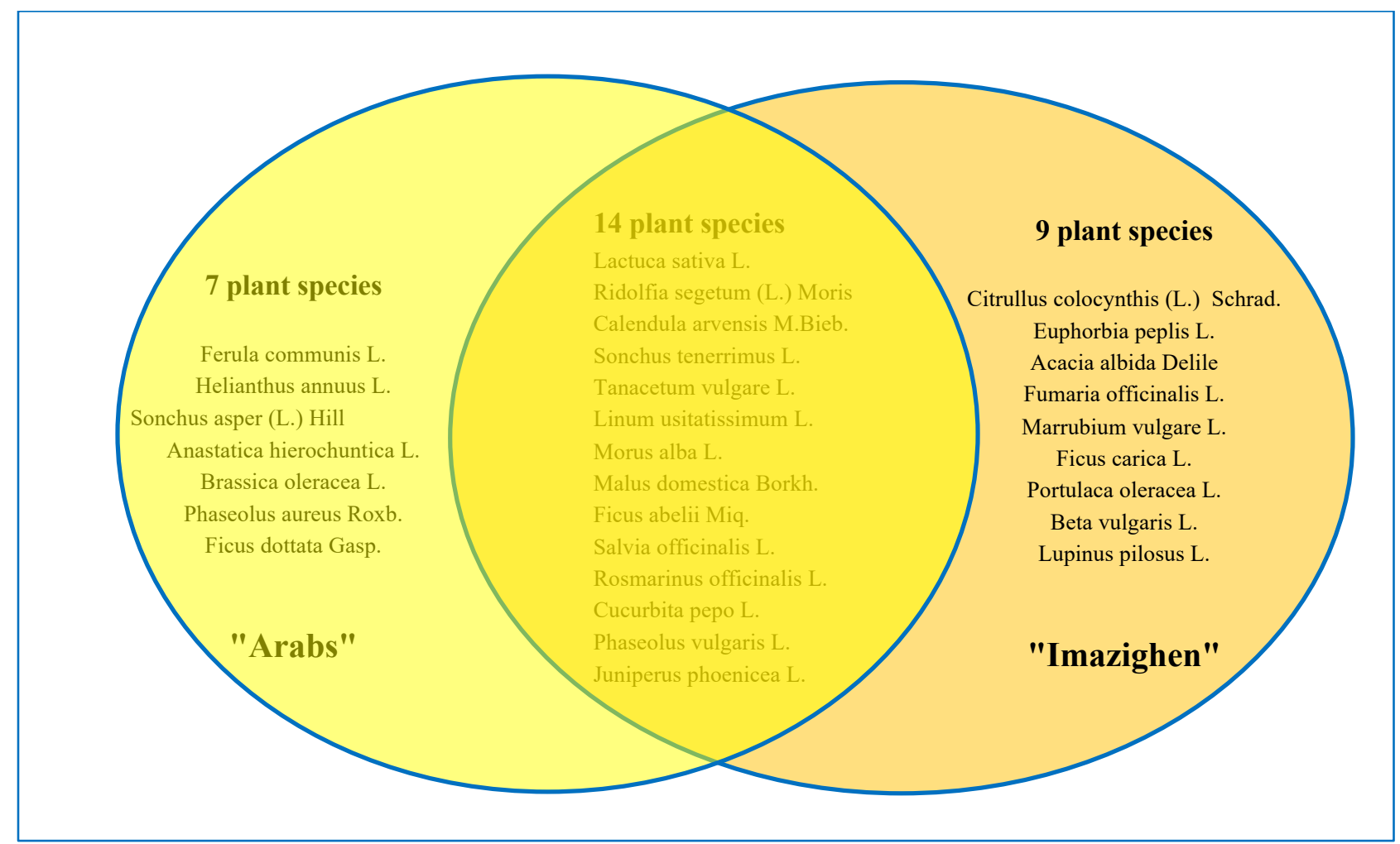

Fig. 4. medicinal plant species registered among the Imazighen and Arabs.

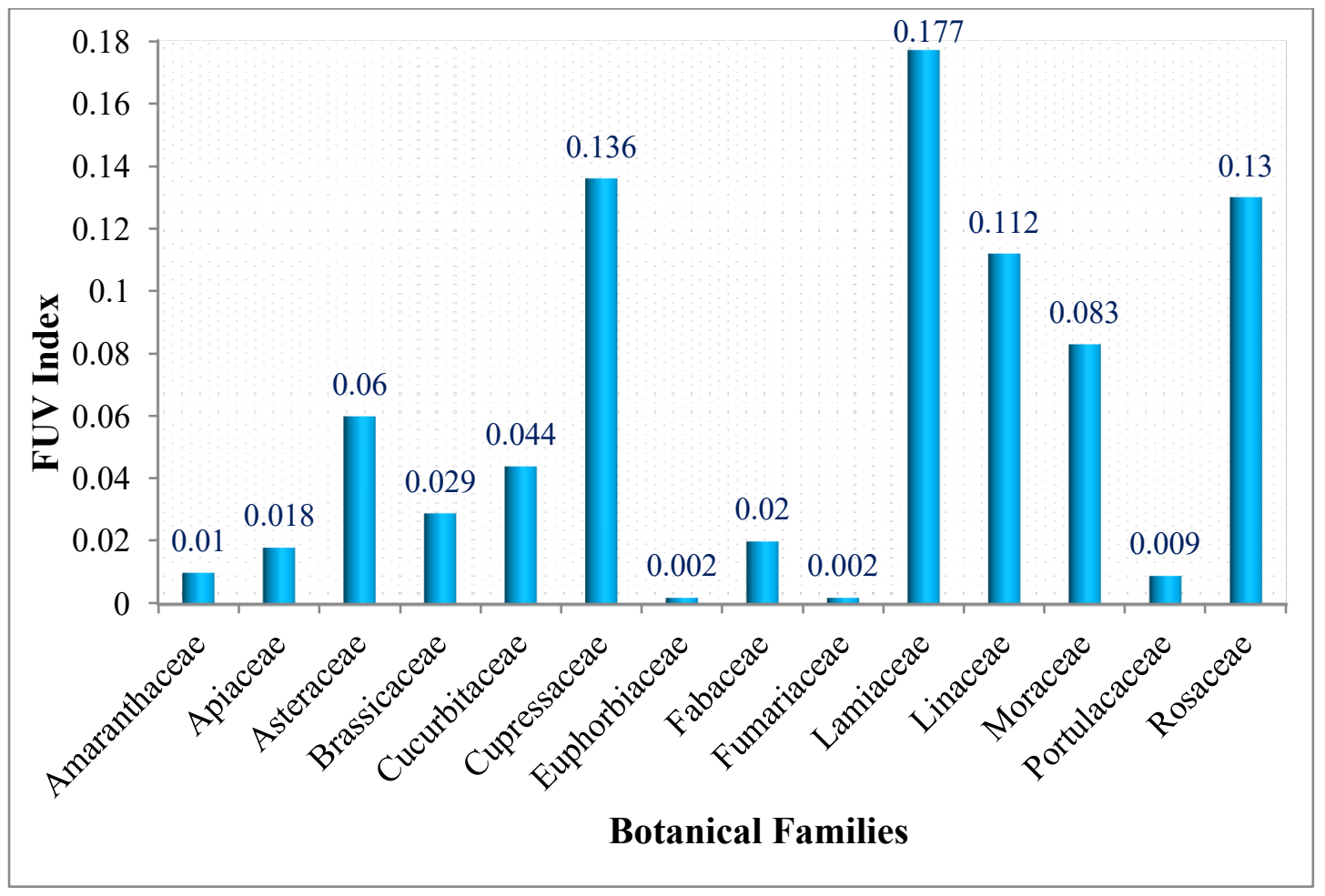

Fig. 5. Family use value (FUV) of MAPs. 
Ethnobotany Research and Applications

Table 2. List of MPs used to cure diabetic problems in the Rif region, Morocco.

\begin{tabular}{|c|c|c|c|c|c|c|c|c|c|}
\hline $\begin{array}{l}\text { Scientific names of species } \\
\text { and families }\end{array}$ & Local name & $\begin{array}{l}\text { Voucher } \\
\text { specimen } \\
\text { number } \\
\end{array}$ & Parts used & Preparation & $\begin{array}{l}\text { Medicinal } \\
\text { uses }\end{array}$ & $\begin{array}{l}\text { Ethnolinguistic } \\
\text { groups }\end{array}$ & UR & UV & FUV \\
\hline Amaranthaceae & & & & & & & & & 0.01 \\
\hline Beta vulgaris $\mathrm{L}$. & 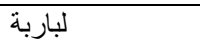 & 289 & Seed & Infusion & TD 1 & Imazighen & 06 & 0.01 & \\
\hline Apiaceae & & & & & & & & & 0.018 \\
\hline Ferula communis L. & لكلخة & 287 & Leaf & Decoction & TD 2 & Arabs & 04 & 0.007 & \\
\hline Ridolfia segetum (L.) Moris. & سليلو & 270 & Leaf & Cooked & TD 1 & Imazighen, Arabs & 17 & 0.029 & \\
\hline Asteraceae & & & & & & & & & 0.060 \\
\hline Lactuca sativa L. & ل لخس & 277 & Leaf & Infusion & GDM & Imazighen, Arabs & 22 & 0.038 & \\
\hline Calendula arvensis M.Bieb. & جمرة, أزويول & 286 & Whole plant & Infusion & TD 1, TD 2 & Imazighen, Arabs & 96 & 0.165 & \\
\hline Helianthus annuus L. & عباد الثمس & 288 & Seed & Infusion & TD 1 & Arabs & 21 & 0.036 & \\
\hline Sonchus tenerrimus L. & ثيفاف & 269 & Leaf & Decoction & TD 2 & Imazighen, Arabs & 25 & 0.043 & \\
\hline Sonchus asper (L.) Hill. & ثيفاف & 285 & Whole plant & Decoction & TD 2 & Arabs & 01 & 0.002 & \\
\hline Tanacetum vulgare $\mathrm{L}$. & البلسم & 278 & Leaf & Infusion & TD 1 & Imazighen, Arabs & 42 & 0.072 & \\
\hline Anastatica hierochuntica L. & شجرة كف مريم & 268 & Root & Decoction & GDM & Arabs & 25 & 0.043 & \\
\hline Brassica oleracea L. & قرنبيط & 276 & Leaf & Other & GDM & Arabs & 09 & 0.015 & \\
\hline Cucurbitaceae & & & & & & & & & 0.112 \\
\hline Cucurbita pepo L. & كر عة خضراء & 266 & Fruit & Cooked & TD 1, TD 2 & Imazighen, Arabs & 43 & 0.074 & \\
\hline $\begin{array}{l}\text { Citrullus colocynthis (L.) } \\
\text { Schrad. }\end{array}$ & ل لحدج, تافرزيزت & 279 & Seed & Infusion & GDM & Imazighen & 09 & 0.015 & \\
\hline Cupressaceae & & & & & & & & & 0.136 \\
\hline Juniperus phoenicea L. & عرعار فينيقي & 267 & Leaf & Decoction & TD 1 & Imazighen, Arabs & 79 & 0.136 & \\
\hline Euphorbiaceae & & & & & & & & & 0.002 \\
\hline Euphorbia peplis L. & لاعية, حليبة & 290 & Whole plant & Other & GDM & Imazighen & 01 & 0.002 & \\
\hline
\end{tabular}

Published: 23 June 2019

http://dx.doi.org/10.32859/era.18.21.1-19 
Ethnobotany Research and Applications

\begin{tabular}{|c|c|c|c|c|c|c|c|c|c|}
\hline Fabaceae & & & & & & & & & 0.020 \\
\hline Lupinus pilosus L. & رجل الدجاجة & 275 & Seed & Infusion & TD 2 & Imazighen & 07 & 0.012 & \\
\hline Acacia albida Delile. & شوك الطلح & 284 & Root & Decoction & GDM & Imazighen & 02 & 0.003 & \\
\hline Phaseolus aureus Roxb. & صوجا & 261 & Seed & Decoction & GDM & Arabs & 02 & 0.003 & \\
\hline Phaseolus vulgaris L. & لوبيا, فاصوليا & 271 & Seed & Cooked & TD 1, TD 2 & Imazighen, Arabs & 36 & 0.062 & \\
\hline Fumariaceae & & & & & & & & & 0.002 \\
\hline Fumaria officinalis L. & حشيشة الصبيان & 283 & Root & Decoction & TD 1 & Imazighen & 01 & 0.002 & \\
\hline Lamiaceae & & & & & & & & & 0.177 \\
\hline Marrubium vulgare L. & مريوت حارة, إفزي & 274 & Leaf & Infusion & GDM & Imazighen & 01 & 0.002 & \\
\hline Salvia officinalis L. & سالمية & 265 & Leaf & Infusion & TD 1, TD 2 & Imazighen, Arabs & 119 & 0.205 & \\
\hline Rosmarinus officinalis L. & أزير , إكليل الجبل & 282 & Leaf & Infusion & TD 1, TD 2 & Imazighen, Arabs & 189 & 0.325 & \\
\hline Euphorbiaceae & & & & & & & & & 0.002 \\
\hline Euphorbia peplis L. & لاعية, حليبة & 290 & Whole plant & Other & GDM & Imazighen & 01 & 0.002 & \\
\hline Fabaceae & & & & & & & & & 0.020 \\
\hline Lupinus pilosus L. & رجل الدجاجة & 275 & Seed & Infusion & TD 2 & Imazighen & 07 & 0.012 & \\
\hline Acacia albida Delile. & شوك الطلح & 284 & Root & Decoction & GDM & Imazighen & 02 & 0.003 & \\
\hline Phaseolus aureus Roxb. & صوجا & 261 & Seed & Decoction & GDM & Arabs & 02 & 0.003 & \\
\hline Phaseolus vulgaris L. & لوبيا, فاصوليا & 271 & Seed & Cooked & TD 1, TD 2 & Imazighen, Arabs & 36 & 0.062 & \\
\hline Fumariaceae & & & & & & & & & 0.002 \\
\hline Fumaria officinalis $\mathrm{L}$. & حشيشة الصبيان & 283 & Root & Decoction & TD 1 & Imazighen & 01 & 0.002 & \\
\hline Lamiaceae & & & & & & & & & 0.177 \\
\hline Marrubium vulgare L. & مريوت حارة, إفزي & 274 & Leaf & Infusion & GDM & Imazighen & 01 & 0.002 & \\
\hline Salvia officinalis L. & سالمبة & 265 & Leaf & Infusion & TD 1, TD 2 & Imazighen, Arabs & 119 & 0.205 & \\
\hline Rosmarinus officinalis L. & أزير , إكليل الجبل & 282 & Leaf & Infusion & TD 1, TD 2 & Imazighen, Arabs & 189 & 0.325 & \\
\hline Linaceae & & & & & & & & & 0.112 \\
\hline Linum usitatissimum L. & زريعة الكتان & 264 & Seed & Cooked & \begin{tabular}{|l|} 
TD 1, TD 2 \\
\end{tabular} & Imazighen, Arabs & 65 & 0.112 & \\
\hline
\end{tabular}

Published: 23 June 2019

http://dx.doi.org/10.32859/era.18.21.1-19 
Ethnobotany Research and Applications

\begin{tabular}{|c|c|c|c|c|c|c|c|c|c|}
\hline Moraceae & & & & & & & & & 0.083 \\
\hline Ficus carica L. & كرموس, شريحة & 280 & Leaf & Infusion & TD 1 & Imazighen & 10 & 0.0172 & \\
\hline Ficus abelii Miq. & كرموس, شريحة & 273 & Leaf & Decoction & TD 2 & Imazighen, Arabs & 103 & 0.177 & \\
\hline Ficus dottata Gasp. & كرموس, شريحة & 262 & Fruit & Other & GDM & Arabs & 11 & 0.019 & \\
\hline Morus alba L. & توت & 263 & Leaf & Infusion & TD 1, TD 2 & Imazighen, Arabs & 68 & 0.117 & \\
\hline Portulacaceae & & & & & & & & & 0.009 \\
\hline Portulaca oleracea L. & رجلة, تسمامين & 272 & Leaf & Cooked & TD 1 & Imazighen & 05 & 0.009 & \\
\hline Rosaceae & & & & & & & & & 0.130 \\
\hline Malus domestica Borkh. & تفاح & 281 & Fruit & Other & TD 1 & Imazighen, Arabs & 76 & 0.130 & \\
\hline
\end{tabular}

TD 1: Type 1 diabetes; TD 2: Type 2 diabetes; GDM : Gestational diabetes mellitus.

Table 3. IAR values by categories for treating diabetic problems.

\begin{tabular}{|l|l|l|l|l|l|l|}
\hline $\begin{array}{l}\text { Ethno } \\
\text { sociolinguistic } \\
\text { groups }\end{array}$ & Ailment Category & $\begin{array}{l}\text { No. of use } \\
\text { reports }\end{array}$ & $\begin{array}{l}\text { \% of use } \\
\text { reports }\end{array}$ & $\begin{array}{l}\text { No. of } \\
\text { Species }\end{array}$ & $\begin{array}{l}\text { \% of all } \\
\text { species }\end{array}$ & IAR \\
\hline \multirow{5}{*}{ Imazighen } & $\begin{array}{l}\text { Type 1 diabetes } \\
\text { (TD 1) }\end{array}$ & 312 & 52.35 & 13 & 43.33 & 0.958 \\
\cline { 2 - 7 } & $\begin{array}{l}\text { Type 2 diabetes } \\
\text { (TD 2) }\end{array}$ & 206 & 34.56 & 10 & 33.33 & 0.951 \\
\cline { 2 - 7 } & $\begin{array}{l}\text { Gestational diabetes } \\
\text { mellitus (GDM) }\end{array}$ & 78 & 13.09 & 5 & 16.67 & 0.936 \\
\hline \multirow{5}{*}{ Arabs } & $\begin{array}{l}\text { Type 1 diabetes } \\
\text { (TD 1) }\end{array}$ & 304 & 53.52 & 13 & 43.33 & 0.957 \\
\cline { 2 - 7 } & $\begin{array}{l}\text { Type 2 diabetes } \\
\text { (TD 2) }\end{array}$ & 198 & 34.86 & 11 & 36.67 & 0.944 \\
\cline { 2 - 7 } & $\begin{array}{l}\text { Gestational diabetes } \\
\text { mellitus (GDM) }\end{array}$ & 66 & 11.62 & 4 & 13.33 & 0.939 \\
\hline
\end{tabular}

Published: 23 June 2019

http://dx.doi.org/10.32859/era.18.21.1-19 


\begin{tabular}{|c|c|}
\hline $\begin{array}{l}\text { - Rosmarinus officinalis } \mathrm{L} .(\mathrm{UV}=0.155) \\
\text { - Salvia officinalis } \mathrm{L} .(\mathrm{UV}=0.103) \\
\text { - Ficus abelii Miq. }(\mathrm{UV}=0.091) \\
\text { - Calendula arvensis } \mathrm{M} . \mathrm{Bieb} .(\mathrm{UV}=0.069) \\
\text { - Morus alba } \mathrm{L} .(\mathrm{UV}=0.065) \\
\text { - Malus domestica } \text { Borkh. }(\mathrm{UV}=0.057) \\
\text { - Juniperus phoenicea } \mathrm{L} .(\mathrm{UV}=0.055) \\
\text { - Linum usitatissimum } \mathrm{L} .(\mathrm{UV}=0.052) \\
\text { - Anastatica hierochuntica } \mathrm{L} .(\mathrm{UV}=0.043) \\
\text { - Helianthus annuus } \mathrm{L} .(\mathrm{UV}=0.036) \\
\text { - Cucurbita pepo } \mathrm{L} .(\mathrm{UV}=0.034) \\
\text { - Tanacetum vulgare } \mathrm{L} .(\mathrm{UV}=0.031) \\
\text { - Phaseolus vulgaris } \mathrm{L} .(\mathrm{UV}=0.029) \\
\text { - Lactuca sativa } \mathrm{L} .(\mathrm{UV}=0.024) \\
\text { - Sonchus tenerrimus } \mathrm{L} .(\mathrm{UV}=0.022) \\
\text { - Ficus dottata } \text { Gasp. }(\mathrm{UV}=0.019) \\
\text { - Brassica oleracea } \mathrm{L} .(\mathrm{UV}=0.015) \\
\text { - Ridolfia segetum }(\mathrm{L} .) \mathrm{Moris}(\mathrm{UV}=0.012) \\
\text { - Ferula abelii } \text { Miq. }(\mathrm{UV}=0.007) \\
\text { - Phaseolus aureus } \text { Roxb. }(\mathrm{UV}=0.003) \\
\text { - Sonchus asper }(\mathrm{L} .) \mathrm{Hill}(\mathrm{UV}=0.002) .\end{array}$ & $\begin{array}{l}\text { - Rosmarinus officinalis } \mathrm{L} .(\mathrm{UV}=0.170) \\
\text { - Salvia officinalis } \mathrm{L} .(\mathrm{UV}=0.101) \\
\text { - Calendula arvensis } \mathrm{M} . \mathrm{Bieb} .(\mathrm{UV}=0.096) \\
\text { - Ficus abelii Miq. }(\mathrm{UV}=0.086) \\
\text { - Suniperus phoenicea } \mathrm{L} .(\mathrm{UV}=0.081) \\
\text { - Malus domestica } \text { Borkh. }(\mathrm{UV}=0.074) \\
\text { - Linum usitatissimum } \mathrm{L} .(\mathrm{UV}=0.060) \\
\text { - Morus alba } \mathrm{L} .(\mathrm{UV}=0.052) \\
\text { - Tanacetum vulgare } \mathrm{L} .(\mathrm{UV}=0.041) \\
\text { - Cucurbita pepo } \mathrm{L} .(\mathrm{UV}=0.040) \\
\text { - Phaseolus vulgaris } \mathrm{L} .(\mathrm{UV}=0.033) \\
\text { - Sonchus tenerrimus } \mathrm{L} .(\mathrm{UV}=0.021) \\
\text { - Ficus carica } \mathrm{L} .(\mathrm{UV}=0.017) \\
\text { - Ridolfia segetum }(\mathrm{L} .) \mathrm{Moris}(\mathrm{UV}=0.017) \\
\text { - Citrullus colocynthis }(\mathrm{L} .) \mathrm{Schrad} . \\
\text { (UV=0.015) } \\
\text { - Lactuca sativa } \mathrm{L} .(\mathrm{UV}=0.014) \\
\text { - Lupinus pilosus } \mathrm{L} .(\mathrm{UV}=0.012) \\
\text { - Beta vulgaris } \mathrm{L} .(\mathrm{UV}=0.010) \\
\text { - Portulaca oleracea } \mathrm{L} .(\mathrm{UV}=0.009) \\
\text { - Acacia albida } \text { Delile }(\mathrm{UV}=0.003) \\
\text { - Euphorbia peplis } \mathrm{L} .(\mathrm{UV}=0.002) \\
\text { - Fumaria officinalis } \mathrm{L} .(\mathrm{UV}=0.002) \\
\text { - Marrubium vulgare } \mathrm{L} .(\mathrm{UV}=0.002)\end{array}$ \\
\hline Arabs & \\
\hline & \\
\hline
\end{tabular}

Fig. 6. UV of plant species by each ethnolinguistic group.

\section{Similarity of illnesses and their IAR values}

Informant agreement ratio (IAR) depends upon the availability of plants within the study area to treat diseases. The authors reported a total of 1164 reports of different diseases categorized into 3 groups. In the present study, the IAR values ranged from 0.936 to 0.958 per uses categories. For both ethnolinguistic groups, the category with the highest degree of agreement from informants was type 1 diabetes related disorders. The ranking followed with type 2 diabetes problems and gestational diabetes mellitus (GDM), the number of use categories per plant species did not differ between Imazighen and Arabs. (Kruskal-Wallis $x^{2}=5.68$, df $=3, p=0.13$ ) shown in Table 3. The IAR results of the study proved that diseases that were frequent in both groups have the higher informant agreement ratio (values between 0.936 and 0.958 ). According to conclusions of (Albuquerque 2002), the highest IARs in the above reported categories represent the common occurrence of reported diseases in the study area and that were treated by specific plants. The informant agreement values also indicated the maximal networking of indigenous people Imazighen and Arabs in the sharing of their knowledge on medicinal practices and this is usually the case with traditional healers to treat the most frequently encountered diseases in the study area. Therefore, species with high IAR are to be prioritized for further on pharmacological and phytochemical studies.

\section{Parts of the MPs used}

In traditional medicine, different parts of plants identified particularly the leaves, flowers, roots, the fruit or even whole plant are exploited by the local population. Based on the plant part value PPV index, leaf was reported as the dominant plant part for diabetic remedy preparation by two ethnolinguistic groups Imazighen (PPV=0.0.548) and Arabs (PPV=0.0.452), PPV values of the other plant parts were varied by ethnolinguistic group (Fig. 7). This indicates that the local healers Arabs and Imazighen 
count on a very well-developed knowledge about the properties of different plant parts. The preference of leaves was due to its easy availability, easy harvesting and simplicity in remedy preparation. In addition, the leaves are the seat of the photosynthesis and sometimes the storage of the secondary metabolites responsible for biological properties of the plant. Similar findings indicated leaf as a major dominant plant part in Morocco (Daoudi et al. 2016; Douiri et al. 2007; Hachi et al. 2015) or in Africa (Asase et al. 2010; Asnake et al. 2016; Mukungu et al. 2016; Nouri 2016) for herbal medicine preparation.

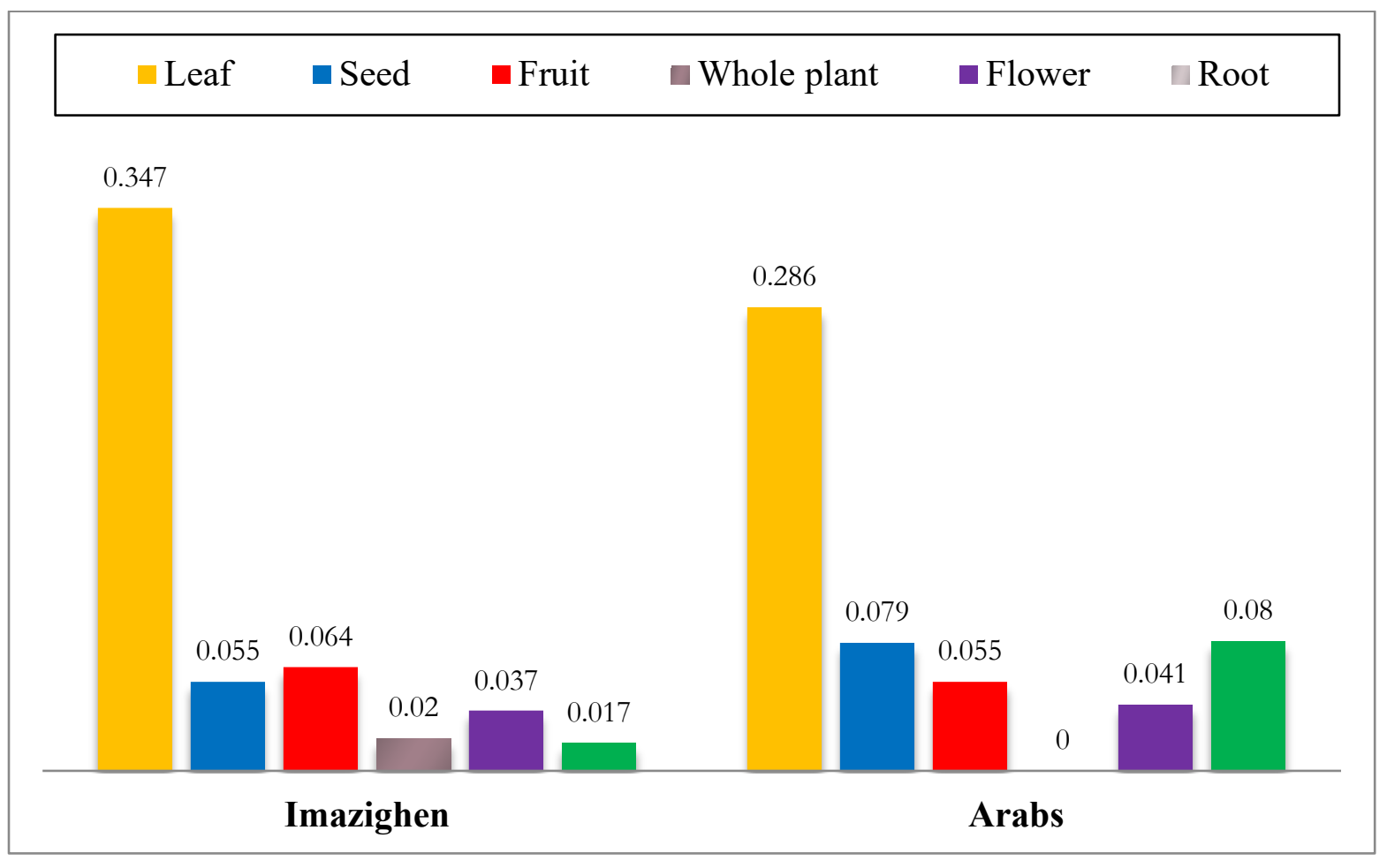

Fig. 7. Plant part used in the treatment of diabetic problems in the study area.

\section{Methods of remedy preparations}

In order to facilitate the administration of the active principles of the plant, several modes of preparation are employed to know decoction, infusion, cataplasm, maceration, fumigation and cooked (Fig. 8). In the study area, information about the preparation of each plant has been included in Table 2. For Imazighen the majorities of remedies were prepared from infusion $(27.46 \%)$, followed by decoction (14.56\%), cooked (7\%) and other methods of preparation $(5.2 \%)$. For Arabs, the primary methods of preparation of remedies were infusion (26.54\%), cooked (8.26\%) and decoction (7.44\%), the percentage of the other methods of preparation grouped (fumigation, maceration, cataplasm, raw) does not exceed $3.64 \%$. In the present study, the majority of informants Imazighen and Arabs indicated that powder is easily prepared and there is very less chance of contamination as compared to maceration or fumigation. The frequent use of the infusion by our informants can be explained by the fact that the infusion makes it possible to collect the most active ingredients and attenuates or cancels out the toxic effect of certain recipes. Ethnobotanical research surveys conducted elsewhere in Morocco showed the majority of the interviewees prepared the remedy by infusion (El Hilah et al. 2015; Salhi et al. 2010; Slimani et al. 2016). This confirms that there is a perpetual exchange of information on the use of medicinal plants between the people of Morocco.

\section{Routes of administration}

In our ethnobotanical survey, the respondent's reports showed that most of the informants Imazighen in the study area administered traditional plant medicines through oral $(40.2 \%)$ followed by massage (3.6\%), other modes of administration $(2.9 \%)$ and swabbing $(1.7 \%)$. For Arabs, the most common one was orally that accounted for $(41.1 \%)$ followed by massage $(6 \%)$, swabbing $(6 \%)$, other modes of administration (1.9\%) rinsing (1\%) and swabbing $(0.8 \%)$. The predominance of oral administration may be explained by a high incidence of internal ailments in the region (Polat and Satıl 
2012). On the other hand, it's thought that oral route is the most acceptable for the patient. The predominance of oral administration of the different MPs in the Rif is in total agreement with most of the carried out ethnobotanical studies in Africa (Benarba et al. 2014; Chermat and Gharzouli 2015; El Hafian et al. 2014).

Source of knowledge about medicinal plants In our ethnobotanical survey, $71.5 \%$ of the population acquired knowledge about medicinal use of plants as remedy for diabetic diseases through others' experiences including $33.2 \%$ of informants Imazighen and $40 \%$ of informants Arabs. This reflects the relative transmission of traditional practices from a generation to the next one. $9.5 \%$ of respondents Arabs and $8.5 \%$ of respondents Imazighen practice herbal medicine according to herbalists' advices, (12\%) of respondents their information is reflected from pharmacist $(4.1 \%$ Imazighen and $2.9 \%$ Arabs) and $1.8 \%$ of the respondents (including 1\% Imazighen and $0.8 \%$ Arabs) had built this knowledge by reading books about traditional Arab medicine, by watching television programs or by their own experience with a large number of MPs in their surroundings. The environment and others' experience remain therefore the most effective means to transmit knowledge about medicinal purposes of plants (Fig. 9).

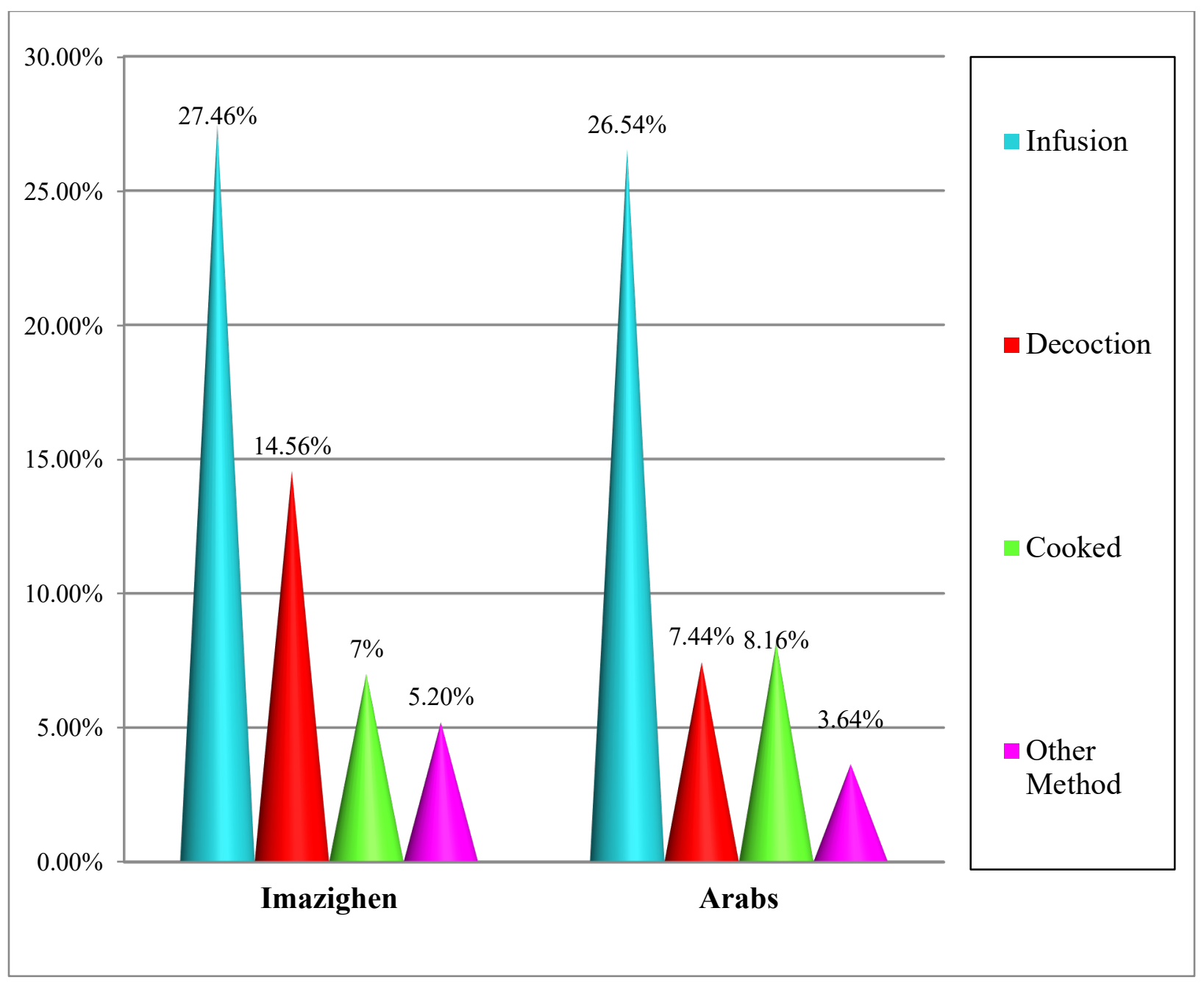

Fig. 8. Frequency of different methods of preparation. 


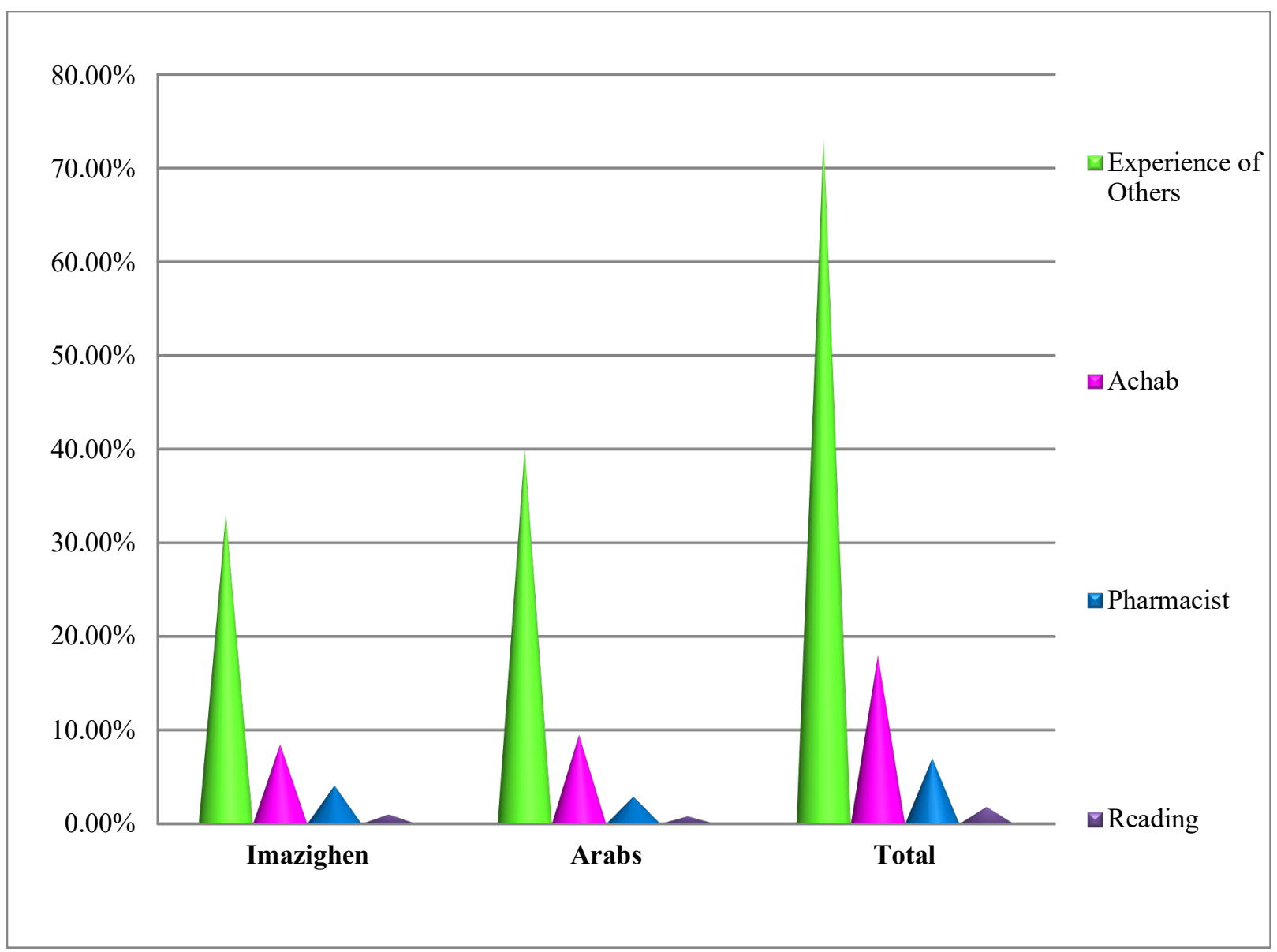

Fig. 9. Traditional knowledge acquisition modes.

\section{Conclusion}

Our study revealed that the local traditional healers of Rif, northern Morocco are rich in ethnomedicinal knowledge and majority of people rely on plant based remedies for common diabetic problems. The survey also revealed that all the traditional healers have strong faith on ethnomedicines although they were less conscious about the documentation and preservation of medicinal plants and ethnomedicinal folklore. Based on the results of this study, higher use value, informant agreement ratio scores of the recorded medicinal plant species would empower the future pharmaceutical and phytochemical studies and conservation practices. In this connection, attention should be drawn to the conservations of traditional medicinal plants and associated indigenous knowledge in the Moroccan Rif area to sustain them in the future.

Limitations of the study

This study was limited to a part of Morocco (Moroccan Rif region). The same study in various parts of Morocco is suggested.

\section{Declarations}

\section{Authors' contributions}

NC: Carried out field research in Rif, compiled the literature sources, data analysis, and interpretation and wrote the manuscript. OB: Helped in data and made a substantial contribution to data analysis. HE: Performed data analysis and drafted the manuscript. RE: Realization and manuscript evaluation. LZ: Designed the research and identification of plant species. All authors read and approved the final manuscript.

\section{Ethics statement and consent to participate}

Letters of consent were taken from department of biology, Ibn Tofail University and an agreement with the local authorities of Chefchaouen, Al Hoceima, Tetouan and Tangier. All data collections were done with special care on the base of the cultural view of the local sites in the study area. Informants were also informed that the objectives of the research were not for commercial purposes but for academic reasons. Participants provided verbal informed consent to participate in this study. They were free to withdraw 
their information at any point of time. Finally, informants were accepted the idea and they have clearly agreed to have their names and personal data to be published.

\section{Funding}

This research did not receive any specific grant from funding agencies in the public, commercial, or notfor-profit sectors.

\section{Conflicts of interest}

We certify that there is no conflict of interest with any financial organization regarding the manuscript.

\section{Availability of data and materials}

All data collected and analyzed in this paper are included within the article and attached in the form of 'Appendices' as additional files. Medicinal and aromatic plant specimens are deposited in Ibn Tofail University, Kenitra, Morocco.

\section{Literature cited}

Albuquerque UP. 2002. Uso e conservação de plantas e animais medicinais no estado de Pernambuco (Nordeste do Brasil): Um estudo de caso. Interciencia, 27(6).

Anyinam C. 1995. Ecology and ethnomedicine. Exploring links between current environmental crisis and indigenous medical practices. pp. 4, 321-329.

Aribi I. 2013. Etude ethnobotanique de plantes médicinales de la région du Jijel: Étude anatomique, phytochimique, et recherche d'activités biologiques de deux espèces.

Asase A, Akwetey GA, Achel DG. 2010. Ethnopharmacological use of herbal remedies for the treatment of malaria in the Dangme West District of Ghana. Journal of Ethnopharmacology, 129(3), 367376.

Asnake S, Teklehaymanot T, Hymete A, Erko B, Giday M. 2016. Survey of medicinal plants used to treat malaria by Sidama People of Boricha District, Sidama Zone, South Region of Ethiopia. EvidenceBased Complementary and Alternative Medicine, 2016.

Benarba B, Meddah B, Tir Touil A. 2014. Response of bone resorption markers to Aristolochia longa intake by Algerian breast cancer postmenopausal women. Advances in Pharmacological Sciences, 2014.

Benlamdini N, Elhafian M, Rochdi A, Zidane L. 2014. Étude floristique et ethnobotanique de la flore médicinale du Haut Atlas oriental (Haute Moulouya). Journal of Applied Biosciences, 78(1), 6771-6787.
Bonet M. 2001. Estudi etnobotànic del Montseny (Ph. D. thesis). Universitat de Barcelona.

Bouzid A, Chadli R, Bouzid K. 2017. Étude ethnobotanique de la plante médicinale Arbutus unedo L. dans la région de Sidi Bel Abbés en Algérie occidentale. Phytothérapie, 15(6), 373-378.

Bulletin officiel. 2015. Bulletin officiel, Décret n² 2-1540 du 1er joumada I 1436 (20 février 2015).

Chermat S, Gharzouli R. 2015. Ethnobotanical study of medicinal flora in the North East of Algeria-An empirical knowledge in Djebel Zdimm (Setif). J Mater Sci Eng, 5, 50-9.

Committee IE. 2009. International Expert Committee report on the role of the $\mathrm{A} 1 \mathrm{C}$ assay in the diagnosis of diabetes. Diabetes Care, 32(7), 1327-1334.

Daoudi A, Bammou M, Zarkani S, Slimani I, Ibijbijen J, Nassiri L. 2016. Étude ethnobotanique de la flore médicinale dans la commune rurale d'Aguelmouss province de Khénifra (Maroc). Phytothérapie, 14(4), 220-228.

Douiri E, El Hassani M, Bammi J, Badoc A, Douira A. 2007. Plantes vasculaires de la Moyenne Moulouya (Maroc oriental). Bull. Soc. Linn. Bordeaux, 142, 409-438.

Eddouks M, Maghrani M, Lemhadri A, Ouahidi ML, Jouad H. 2002. Ethnopharmacological survey of medicinal plants used for the treatment of diabetes mellitus, hypertension and cardiac diseases in the south-east region of Morocco (Tafilalet). Journal of Ethnopharmacology, 82(2-3), 97-103.

El Hafian M, Benlandini N, Elyacoubi H, Zidane L, Rochdi A. 2014. Étude floristique et ethnobotanique des plantes médicinales utilisées au niveau de la préfecture d'Agadir-Ida-Outanane (Maroc). Journal of Applied Biosciences, 81(1), 7198-7213.

El Hilah FBA, Dahmani J, Belahbib N, Zidane L. 2015. Étude ethnobotanique des plantes médicinales utilisées dans le traitement des infections du système respiratoire dans le plateau central marocain. Journal of Animal \&Plant Sciences, 25(2), 3886-3897.

Fennane M, Tattou MI, Mathez J, Quézel P. 1999. Flore pratique du Maroc: Manuel de détermination des plantes vasculaires. Pteridophyta, Gymnospermae, Angiospermae (LauraceaeNeuradaceae). Institut scientifique.

Ghourri M, Zidane L, Rochdi A, Fadli M, Douira A. 2012. Etude floristique et ethnobotanique des plantes médicinales de la ville d'El Ouatia (Maroc Saharien). Kastamonu Üniversitesi Orman Fakültesi Dergisi, 12(2), 218-235. 
Godron M. 1971. Essai sur une approche probabiliste de l'écologie des végétaux. Thèse de Doctorat, p. 247 p.

Goldenberg R, Punthakee Z. 2013. Definition, classification and diagnosis of diabetes, prediabetes and metabolic syndrome. Canadian Journal of Diabetes, 37, S8-S11.

Graham JE, Stoebner-May DG, Ostir GV, AI Snih S, Peek MK, Markides K, Ottenbacher KJ. 2007. Health related quality of life in older Mexican Americans with diabetes: A cross-sectional study. Health and Quality of Life Outcomes, 5(1), 39.

Hachi M, Hachi T, Belahbib N, Dahmani J, Zidane L. 2015. 'Contribution à l'étude floristique et ethnobotanique de la flore médicinale utilisée au niveau de la ville de khenifra (Maroc)'. International Journal of Innovation and Applied Studies, 11(3), 754.

HCP. 2018. Haut-commissariat au plan, Monograpie de la région Tanger Tétouan Al Hoceima, Direction Régionale de Tanger-Tétouan-Al Hoceima.

Heinrich M, Ankli A, Frei B, Weimann C, Sticher O. 1998. Medicinal plants in Mexico: Healers' consensus and cultural importance. Social Science \& Medicine, 47(11), 1859-1871.

International Diabetes Federation.

(2019). https://www.idf.org/our-network/regionsmembers/middle-east-and-northafrica/members/37-jordan.html.

Jain SK. 1964. The role of botanist in folklore research. Folklore, 5(4), 145-150.

Jouad H, Haloui M, Rhiouani H, El Hilaly J, Eddouks M. 2001. Ethnobotanical survey of medicinal plants used for the treatment of diabetes, cardiac and renal diseases in the North centre region of Morocco (FezBoulemane). Journal of Ethnopharmacology, 77(23), 175-182.

Karami S, Roayaei M, Hamzavi H, Bahmani M, Hassanzad-Azar H, Leila M, Rafieian-Kopaei M. 2017. Isolation and identification of probiotic Lactobacillus from local dairy and evaluating their antagonistic effect on pathogens. International Journal of Pharmaceutical Investigation, 7(3), 137.

Lahsissene H, Kahouadji A, Hseini S. 2009. Catalogue des plantes medicinales utilisees dans la region de Zaër (Maroc Occidental). Lejeunia, Revue de Botanique.

Mukungu N, Abuga K, Okalebo F, Ingwela R, Mwangi J. 2016. Medicinal plants used for management of malaria among the Luhya community of Kakamega East sub-County, Kenya. Journal of Ethnopharmacology, 194, 98-107.

Nouri J. 2016. Étude floristique et ethnobotanique des plantes médicinales au nord-ouest de la Tunisie: Cas de la communauté d'Ouled Sedra. Journal of Advanced Research in Science and Technology, 3(1), 281-291.

Polat R, Satıl F. 2012. An ethnobotanical survey of medicinal plants in Edremit Gulf (Balıkesir-Turkey). Journal of Ethnopharmacology, 139(2), 626-641.

Rabiei Z, Gholami M, Rafieian-Kopaei M. 2016. Antidepressant effects of Mentha pulegium in mice. Bangladesh Journal of Pharmacology, 11(3), 711715.

Salhi S, Fadli M, Zidane L, Douira A. 2010. Etudes floristique et ethnobotanique des plantes médicinales de la ville de Kénitra (Maroc). Lazaroa, 31, 133.

Sijelmassi A. 1993. Les plantes médicinales du Maroc, 3ème édition Fennec. Casablanca, Moroc.

Slimani I, Najem M, Belaidi R, Bachiri L, Bouiamrine EH, Nassiri L, Ibijbijen J. 2016. Étude ethnobotanique des plantes médicinales utilisées dans la région de Zerhoun-Maroc-[Ethnobotanical Survey of medicinal plants used in Zerhoun regionMorocco-]. International Journal of Innovation and Applied Studies, 15(4), 846.

Sreekeesoon DP, Mahomoodally MF. 2014. Ethnopharmacological analysis of medicinal plants and animals used in the treatment and management of pain in Mauritius. Journal of Ethnopharmacology, 157, 181-200.

Tahraoui A, El-Hilaly J, Israili ZH, Lyoussi B. 2007. Ethnopharmacological survey of plants used in the traditional treatment of hypertension and diabetes in south-eastern Morocco (Errachidia province). Journal of Ethnopharmacology, 110(1), 105-117.

Valdés B. 2002. Catalogue des plantes vasculaires du Nord du Maroc, incluant des clés d'identification (Vol. 1). Editorial CSIC-CSIC Press.

Vitalini S, Iriti M, Puricelli C, Ciuchi D, Segale A, Fico G. 2013. Traditional knowledge on medicinal and food plants used in Val San Giacomo (Sondrio, Italy)_An alpine ethnobotanical study. Journal of Ethnopharmacology, 145(2), 517-529.

Ziyyat A, Legssyer A, Mekhfi H, Dassouli A, Serhrouchni M, Benjelloun W. 1997. Phytotherapy of hypertension and diabetes in oriental Morocco. Journal of Ethnopharmacology, 58(1), 45-54. 


\section{Appendix A}

Questionnaire sheets: Medicinal plants and herbal medicine

Date...

Region

Commune

Survey number.

Informant:

Profession:

Sex:

Male

Female

Age: $\quad\{\leq 20\}$

$\square$
Single $\square$

$\square$

Divorced $\square$ Widower $\square$

$\{\geq 60$

Family situation:

Illiterate $\square \quad$ Primary $\square \quad$ Secondary $\square$

Level of study:

Nomadic

Town

Village $\square$

Married $\square$

Locality:

Income / month (MAD): Unemployed

] $\{250-1500\}$

$\{1500-5000\}$

University

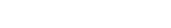

\section{Therapeutic practices:}

When you feel sick, you address:

To traditional medicine, why?

$$
\text { Effective }
$$

To modern medicine, why?

If it is two that it is the first:
Cheapest $\square$ Acquisition Effective $\square$ More precise

Traditional medicine
Ineffective medication

Toxicity of plants

Modern medicine

\section{Vegetal material:}

Vernacular name:

Scientific Name:

Plant Type:

$$
\text { Spontaneous }
$$

Therapeutic

Use of the plant:

Harvesting technique:

Harvest Time:

Drug preparation:

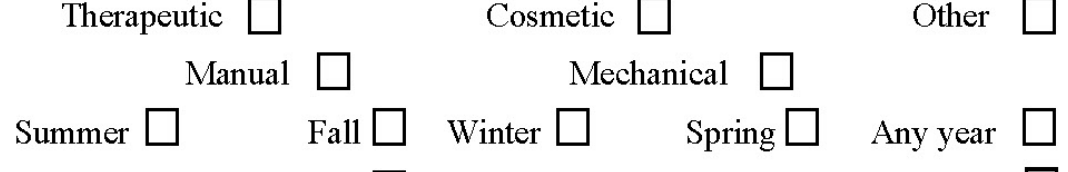

Plant alone $\square \quad$ Possible association (of plants)

If association of plants, quote the recipe:.

Use of the plant:

Fresh

Desiccated

After treatment

If desiccated, drying method:

Sun exposure

In the Shade 


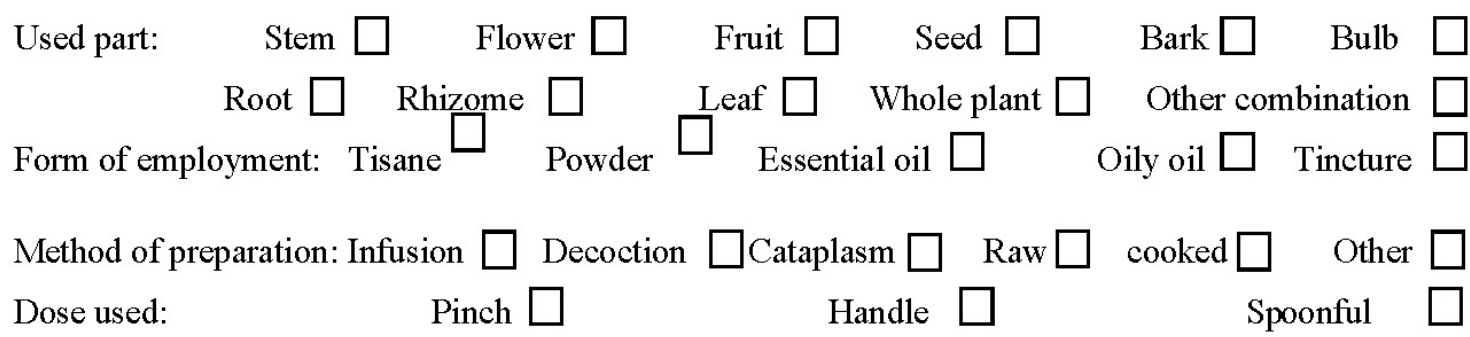

Precise Dose: Quantity in $\mathrm{g}$ / glass: ........... Quantity in $\mathrm{g} /$ liter: ......... Other:

Administration mode: $\quad$ Oral $\square \quad$ Massage $\square \quad$ Rinse $\square \quad$ Swabbing $\square$ Other $\square$

Dosage: number of doses per day:

For children: 1time/day $\square \quad$ 2time/day $\square \quad$ 3time/day $\square \quad$ Other $\square$

For adults: $\quad$ 1time/day $\quad \square \quad$ 2time/day $\square \quad$ 3time/day $\square \quad$ Other $\square$

For older people: $\quad$ 1time/day $\square \quad$ 2time/day $\square \quad$ 3time/day $\square \quad$ Other $\square$

Length of Use: $\quad$ One Day $\square \quad$ A Week $\square \quad$ One month $\square \quad$ Until healing $\square$

Conservation method: $\quad$ Sheltered from the light $\square \quad$ Exposed to light $\square \quad$ Other $\square$

Expiration date:

$\underline{\underline{\text { Use: }}}$

\begin{tabular}{|c|c|c|c|c|c|}
\hline Diagnosis By: & Himself $\square$ & Doctor & $\square$ & Herbalist $\square$ & Other \\
\hline Results: & Healing $\square$ & & Improvement & $\square$ & Ineffective \\
\hline
\end{tabular}

